\title{
Agenda entrance complexity in international accounting standard setting: the case of IFRS for SMES
}

Article

Accepted Version

Ram, R. and Newberry, S. (2017) Agenda entrance complexity in international accounting standard setting: the case of IFRS for SMEs. Abacus, 53 (4). pp. 485-512. ISSN 1467-6281 doi: https://doi.org/10.1111/abac.12122 Available at https://centaur.reading.ac.uk/67246/

It is advisable to refer to the publisher's version if you intend to cite from the work. See Guidance on citing.

To link to this article DOI: http://dx.doi.org/10.1111/abac.12122

Publisher: Wiley-Blackwell

All outputs in CentAUR are protected by Intellectual Property Rights law, including copyright law. Copyright and IPR is retained by the creators or other copyright holders. Terms and conditions for use of this material are defined in the End User Agreement.

www.reading.ac.uk/centaur 
Central Archive at the University of Reading

Reading's research outputs online 


\section{Agenda Entrance Complexity in International Accounting Standard Setting: the Case of IFRS for SMEs}

RONITA RAM AND SUSAN NEWBERRY

Ronita Ram ( Ronita.Ram@henley.ac.uk), Henley Business School;

Susan Newberry (usan.newberry@sydney.edu.au), University of Sydney Business

School.

\section{Abstract}

Features of rational decision making (such as agenda entrance criteria and statement of jurisdiction) barely conceal the complexity of international accounting standard setting. In 2003, when the international financial reporting standard for small and medium-sized entities (IFRS for SMEs) project achieved agenda entrance, the International Accounting Standards Board's (IASB) jurisdiction was to develop, 'a single set of ... accounting standards ... to help participants in the world's capital markets'. Drawing on interviewees' recollections and other material, this study of how the project achieved agenda entrance finds within-IASB opposition to the project, arguing it was outside the IASB's jurisdiction that dissolved with the realisation that the IASB's jurisdiction would be changed to encompass the project.

Earlier accounting works have shown that an understanding of agenda entrance is critical to understanding the accounting standard setting process. Consider Walker and Robinson (1993; 1994) and Ryan (1998). Kingdon's (2011) model of agenda entrance helps to show the complexity of the politics and decision making messiness that resulted in a standard setting project for simplified IFRS but titled IFRS for SMEs. The complexity was particularly associated with: (i) the broader international regulatory context requiring adaptation; (ii) the limitations of ostensibly technical barriers to agenda entrance, including the boundary of the IASB's standard-setting jurisdiction; (iii) jurisdictional competition; and (iv) sensitivities over the language such that the IASB could not agree on a suitably descriptive title. The paper responds to calls for attention to actions of individual board members and staff (Walker and Robinson, 1993; Howieson, 2009). 
Key terms: agenda entrance, complexity, IASB, international accounting standard setting, IFRS for SMEs, jurisdiction

Running title: Agenda Entrance Complexity and IFRS for SMEs

Accounting standard setting at national levels has long been known as complex, being interrelated with other events, and politicized (Solomons, 1983;

Walker and Robinson, 1993 and 1994; Young, 1994; Zeff, 2002). This complexity is magnified at the international level where accounting standard setters must also cope with many countries at different stages of capital market development and different business cultures (Howieson, 2009; Camfferman and Zeff, 2015). Adding to that are the International Accounting Standards Board's (IASB) alliances on accounting matters with other international bodies, such as the 1995 agreement with the International Organization of Securities Commissions (IOSCO) to focus international accounting standards on financial reporting for investors in capital markets (Klumpes, 1994; Walker and Robinson, 1994; Young, 1994; Johnson and Swieringa, 1996; Ryan, 1998; Jones et al., 2004; Howieson, 2009; Crawford et al., 2014). In such an environment, there is a need for accounting standard setting to adapt to changing circumstances (Whittington, 2015), and ostensibly technical boundaries such as a tightly specified jurisdiction and/or agenda entrance criteria may become barriers to adaptation.

This study reviews the emergence of the IASB's International Financial Reporting Standard for Small and Medium sized Entities (IFRS for SMEs) project onto the IASB's standard setting agenda in 2003. The project title implied a departure from the IASB's constitutional focus on capital market participants, thus prompting the question how it achieved agenda entrance. A combination of factors, rather than 
any single factor, is likely to generate a 'climate of receptivity' for entrance onto the accounting standard setting agenda (Walker and Robinson, 1994; Ryan, 1998). Among those factors are decisions about the nature and scope of a problem, the language in which it is formulated, and how to resolve it (Klumpes, 1994; Walker and Robinson, 1994; Young, 1994; Johnson and Swieringa, 1996; Ryan, 1998; Jones et al., 2004; Howieson, 2009). Agenda entrance decisions involve the actions of individual board members and staff, and yet these have received little research attention (Walker and Robinson, 1993; Howieson, 2009). This research reveals the power and influence wielded by key board members to overcome within-IASB opposition to the project and secure its agenda entrance. Additionally, it demonstrates the differences in power between key board members who wanted the SME project on the IASB's standard setting agenda, and technical staff who held reservations about that.

At the centre of the politics surrounding agenda entrance for cash flow reporting in Australia, Walker and Robinson (1994) reported conflict among regulators for jurisdiction and support, and recommended research attention to the way jurisdiction is defined, as well as to the interactions between different regulatory agencies. Similar to Walker and Robinson, the present study finds evidence of conflict over jurisdiction, in particular, over whether the IASB should 'seize or cede' the accounting standard-setting role for entities that do not issue debt or equity instruments for trading in public capital markets (World Standard Setters, 2003). However, the jurisdictional competition may have seemed greater than it really was, helping to subdue within-IASB conflict over the IASB's jurisdiction and thus to accelerate the agenda entrance decision and extend its jurisdiction. 
The complexity of any international standardization exercise that detaches 'accounting standardization from existing national traditions', but must also allow for local variations, has posed particular problems for the IASB (Botzem, 2012, p.5). This is so here as the board was trying to counter the tendency of some companies to claim compliance with international standards while applying them only selectively, that practice having become known as applying IAS lite (Cairns, 2001; Botzem, 2012). Especially illustrated is the importance of language in standard setting (Walker and Robinson, 1994; Howieson, 2009; Kingdon, 2011). This study shows that the SME language used focused attention on an agreed position that SMEs should not be required to apply the full IASB standards, while deflecting it from the IASB's known inability to devise a size-based definition of an SME for international application. The implications of a project to produce a simplified version of the IASB's standards for wider application received little attention.

This study draws on Kingdon's (2011) model of agenda setting to understand how the SME project achieved agenda entrance. According to Kingdon, a single influencing factor is an unlikely trigger for agenda entrance; rather 'a complex of factors' is more likely to be involved (Kingdon, 2011 p.49).

\section{AGENDA SETTING}

Kingdon compares agenda setting to organized anarchy, arguing that rational process models of policy making do not 'very accurately describe reality' (p.79). He draws on the US Presidential system of government to explain his model which, although developed in the US political context, is now used increasingly outside the US (Eissler et al., 2014), and in the context of international regulatory regimes (see, for example, studies of policy making in the EU, such as Zahariadis, 2008; Ackrill and Kay, 2011; Alexandrova et al., 2012; Bache, 2013; Palmer, 2015). While other 
models such as Cobb and Elder's (1972), and Mitnick's (1980) have proved useful in studies of accounting standard-setting, they pay relatively less attention than Kingdon to agenda entrance and are less suitable here. Kingdon's model has been used in accounting studies (see for example, Ryan, 1998), and more importantly proved useful in other complex environments where multiple problem formulations and potential policy solutions may exist (Morris, 1999; Ackrill et al., 2013). The IASB exists in such an environment, having emerged as part of the international regime regulating global financial markets, and yet the extension of its jurisdiction beyond those financial markets to accommodate the SME project means the IASB arguably now claims 'to represent the general logic of globalized capitalism' (Botzem, 2012, p.179).

According to Kingdon, agenda setting in an organized anarchy involves organized patterns and structures. Elected officials, especially those at high levels, hold the formal authority and institutional resources to make appointments to policy positions, to establish a tone, and to decide some key issues when setting the agenda. But this organizational authority is tempered by the influence of other participants in the process (both internal and external) who engage in more detail and consequently tend to have greater effect on policy alternatives and implementation.

Recognizing that many people may participate in agenda-related activities, Kingdon identifies two general groupings, those who are visible and those who are relatively hidden. He proposes the agenda is typically most affected by visible participants, those who tend to receive 'press and public attention' such as those holding high level appointments (Kindgon, 2011, p.68). The relatively hidden participants, such as staff and researchers, are more likely to generate policy alternatives than to determine what is on the agenda. Interest groups range between 
visible and relatively hidden groups; further, some interest group activities may be conducted publicly and others relatively invisibly.

In the case of the IASB, board members may be characterized as visible participants with the chairman the most visible and organizationally powerful. The first chairman of the IASB, Sir David Tweedie, was also its chief executive, holding a level of power and resources Kingdon regards as presidential. Staff members may be identified, but they tend to be relatively hidden, their technical role implying a greater influence in proposing policy alternatives and implementation than in setting the agenda. At this international level the most visible interest groups include alliance partner organisations, such as the World Bank and IOSCO, while the less visible groups are some of those associated with particular policy interests.

Kingdon (pp.3-4) distinguishes between a broad concept of an agenda as a list of topics receiving 'serious attention at any given time', and the decision agenda as the list of items 'that are up for an active decision.' As will become apparent, the SME project was on the IASB's broader technical agenda from the time of its establishment. The focus here is on how that project entered the IASB's decision agenda, that is, its standard setting agenda.

To conceptualize the agenda-setting process, Kingdon identifies three concurrent streams of activity ('problem', 'policy' and 'politics'). Each stream has its own origins and dynamics, and flows relatively independently of the others, while interaction between them sets the boundaries for policy debate and potential policy solutions. No stream has sufficient force on its own for an item to achieve agenda entrance or remain there, that outcome becoming more likely when the streams converge. Accordingly, agenda entrance is unlikely to result from a single factor, but 
rather from 'the joint effect of several factors coming together at a given point in time' (p.179).

The problem stream involves formulating a particular condition as a problem in need of a policy response (Kingdon, 2011). How a problem is formulated and categorized structures perceptions of it, so language and persuasiveness are important considerations. Indeed, a new category of problem may prompt 'entirely new definitions of problems and conceptualizations of solutions' (Kingdon 2011, p.111).

Problem formulation determines, inter alia, whether a problem falls within a policy maker's jurisdiction, the problem's suitability for the policy maker's capabilities, and its likely effect on the budget. How a problem is formulated will benefit some parties at the expense of others, and affects a policy maker's willingness to accept it as an agenda item. The chances of even quite a pressing problem achieving agenda entrance are low in the absence of other factors, but may be 'dramatically increased' if that problem is linked with a policy proposal (p.142).

Policy proposals are developed in the policy stream of agenda-setting activity, where multiple policy communities with varying levels of power, authority, visibility and capacity interact (Robinson, 2000; Kingdon, 2011). These policy proposals may emerge to solve a known policy problem, or they may emerge for other reasons, such as to suit particular interests (Kingdon, 2011).

Within any policy community, policy proposal development occurs within limits, compatibility with the values of the policy community members being important if the proposal is to receive serious consideration. Obvious practical limits include feasibility and constrained resources. However, a policy proposal also needs to win political approval and wider public acceptance for it to proceed further. 
In some policy communities, policy entrepreneurs, people with some claim to be heard such as leadership of a professional or particular interest group, those with other political connections or negotiating skills, and possibly some authoritative decision making power of their own, will try to win the necessary political approval and public acceptance. In doing so, a policy entrepreneur may function as both policy broker and policy advocate. As broker, a policy entrepreneur may bend a particular problem to suit that entrepreneur's policy proposal, and is assisted in any negotiations by some vagueness in the policy proposal. As advocate, a policy entrepreneur may be expected to lobby and speak publicly seeking to influence the policy community itself, other policy communities and the relevant public (Ackrill and Kay, 2011; Kingdon, 2011). Thus, a policy entrepreneur's activities help to bridge the policy stream where acceptance of policy proposals is built by reasoning, and the politics stream, where agreement to support a particular policy proposal is facilitated by bringing together 'diverse interests' and bargaining (Kingdon, 2011, p.161).

The politics stream of activity encompasses the broader context that affects a policy maker's willingness to accept a problem onto its agenda (Kingdon, 2011). Among the contextual influences are pressures exerted by external or internal interest groups, the public mood, and the policy maker's own interests, including jurisdictional interests, and changing priorities and personnel (Robinson, 2000; Kingdon, 2011). This politics stream is an important "promoter or inhibiter of high agenda status' (Kingdon, 2011, p.163).

Interest group pressures and public mood influence, but do not necessarily determine, a policymaker's willingness to act. Problems that are consistent with the public mood and/or interest group pressure may be more easily accepted for agenda 
entrance, while those that are inconsistent may require reformulation to suit the mood, or be delayed until the mood changes.

In the presence of jurisdictional competition, a problem that fits within the jurisdiction may be moved onto the agenda quickly (Kingdon, 2011). Jurisdictional competition, however, tends to reinforce other influences rather than to determine agenda entrance: 'If the complex of political and policy forces are already balanced against an issue, competition for [jurisdictional] turf will drive the last nail into the coffin. But if that same balance tilts toward the issue, competition will contribute its share to moving the issue along' (p.158).

Finally, changes in the policy maker's own interests, priorities and personnel affect what may be considered for agenda entrance. For example, those in positions of authority may hold their own views about agenda entrance priorities, and will themselves eventually change, with a resulting effect on the agenda.

Opportunities for agenda entrance, known as a policy window, are brief and limited, an already full agenda and budget constraints imposing obvious limitations. Occasionally, the timing of such an opportunity will be predictable, such as when agenda items are being ordered and re-ordered. Similarly predictable are some events in the politics stream, such as a scheduled change of key personnel that may lead to openings for problem and policy ideas. At other times an opportunity may occur with little warning, perhaps because a problem has become pressing or has caught officials' attention. That may in turn prompt a search of the policy stream for a policy proposal, preferably already considered acceptable, 'that can reasonably be seen as a solution' (p.174).

When a policy window opens, various policy advocates may be expected to use the opportunity to promote their proposal. Because various loose couplings of 
problem formulation and policy solution are possible, a policy advocate may attach a proposal to a problem that suits the politics of the time and 'enlist political allies' to support it (p. 182). Especially when the intent behind that proposal does not provide an acceptable reason for change on its own, coupling it with a different problem may help to provide cover. Consequently, a policy proposal may easily become attached to a problem that 'did not necessarily dictate' that as the solution (p.177). This can mean that those with power over decisions to open a policy window risk a policy outcome that is 'worse than the status quo', while those opposed to a particular policy proposal may try to force delays hoping for the window to close in the meantime (p.175).

According to Kingdon, when agenda entrance occurs, the critical event to understand is how the three streams of agenda-setting activity come together, and often just one or a few people will be central to that. However, he warned that the impact on the agenda differs 'from control over the alternatives or over the outcomes' (p.164). After an item has achieved agenda entrance and 'organized forces enter the picture, trying as best they can to bend the outcomes to their advantage', the outcome of the project will 'depend on the mix of elements present and how the various elements are coupled' (pp.163, 166).

\section{RESEARCH METHOD}

Events and related documents concurrent with the establishment of the IASB in early 2001, and through to September 2003, shortly after the SME project was placed on the IASB's active standard-setting agenda are reviewed. The IASB did not, initially, have documented agenda setting procedures, and such documentation did not emerge until 2006 (Howieson, 2009). By 2003, the IASB did provide some vague description on its website about how it made its agenda setting decisions, but that description was 'silent on the process and criteria used by IASB members to formally 
admit projects to the technical agenda once potential projects had been identified'

(Howieson, 2009, p. 592) ${ }^{1}$. There is, therefore, no published formal due process

against which to assess the IASB's decision on this project. We draw upon Kingdon's

(2011) model of agenda-setting activities to understand how the project achieved

entrance onto the IASB's standard-setting agenda.

The pre-agenda entrance stage of accounting standard setting has received scant research attention and insights obtained contribute to our knowledge of this period (Walker and Robinson, 1994; Howieson, 2009). Both documentary analysis and interviews are drawn upon. ${ }^{2}$ Interviews provide the prospect for gaining insight into events that might not have been documented. However, interviewees may: have limited knowledge or recollection, provide a biased account of events, or withhold information (Richards, 1996). The 16 interviewees were IASB members involved in, or observers of, the development of the IFRS for SMEs standard. Some held multiple roles (see Table 1). They include both supporters and opponents of the project. All

${ }^{1}$ The relevant text of that 2003 description as reproduced by Howieson (2009, p.591), was:

'How does the IASB decide what subjects to add to its agenda? Board Members, members of the Standards Advisory Council, National Standard Setters, securities regulators, other organizations and individuals and the IASB staff are encouraged to submit suggestions for new topics which might be dealt with in their accounting standards.

The International Organization of Securities Commissions (IOSCO), which represents securities market regulators around the world, completed a review of IASC Standards in 2000, and their Report contained several areas where their members would like to see improvements in IAS. The IASB Staff are working with IOSCO to determine priorities.'

${ }^{2}$ Published documents include those available from the IASB's website: IASB project updates, reports of IASB meetings and of the IASB's Standards Advisory Council meetings; and initial consultation documents issued as the public due process commenced for the SMEs project. Unpublished material includes International Standard-setting Reports (IStaR) which provide more details about IASB meetings than the IASB's own reports, and internal IASB material presented to the September 2003 meeting of World Standard-setters. Additional published documentary material comes from the World Bank, and from the United Nations Conference on Trade and Development's (UNCTAD) group of experts on International Standards of Accounting and Reporting (ISAR). While the group is known as ISAR, the published material is issued by UNCTAD and is listed as such in the references list. 
interviewees signed an ethics-approved participant consent form in which they agreed they could be identified, and that they would have the opportunity to review and correct the interview transcript and to identify any information they did not want cited. Fifteen interviews were conducted in 2008, and a further one in November 2011 to clarify matters that emerged in the process of analysing the data. Most interviews were conducted in person in November 2008, although four were telephone interviews (those with Thomas Jones, Nelson Carvhallo, Peter Walton, and Geoffrey Whittington). The interviews ranged from 15 minutes to one hour, and the questions were open-ended, relating to the particular aspects of the SME project with which the interviewee was familiar. All interviews were recorded, transcribed and forwarded to the interviewees to review and identify any information they wished not to be cited. No interviewee asked for any material to be removed or not cited.

[Insert Table 1 here]

Within the IASB, the project was known as the SME project even though the title was known to be not necessarily appropriate. For simplicity, that term for the project is also used here. An outline of the relevant events before the IASB's establishment, and some initial pressures on its standard setting agenda provides context for examining agenda entrance of the SME project.

\section{THE IASB AND THE DEVELOPMENT OF IFRS FOR SMES}

\section{Context prior to establishment of IASB}

For nearly two decades prior to 1995 when the IASB's predecessor, the International Accounting Standards Committee (IASC) narrowed its standard setting focus to investors in capital markets, there were warning signs in both developed and lesser developed countries that application to all entities would be unworkable. In 
developed countries, where standard-setters had already prioritized capital market participants, the standards had been criticized as too difficult to apply, producing overly complex information often beyond the decision making needs of the users of financial statements of smaller companies, and as imposing excessive compliance costs (see for example, Hepp and McRae, 1982; Carsberg et al., 1985). The differential reporting regimes devised in response to such complaints allowed departures 'from some particular requirements of accounting standards or the entire accounting standards' (Hepp and McRae, 1982; Abdel Khalik, 1983; Carsberg et al., 1985; Harvey and Walton, 1996; CAPA 2003, p.7). ${ }^{3}$ Standard-setters paid little attention to user needs when providing differential reporting concessions, seeking instead to reduce compliance costs (Jarvis, 1996).

The United Nations Conference on Trade and Development (UNCTAD) had established a working group of experts on International Standards of Accounting and Reporting (ISAR). Once perceived as a rival of the IASC, ISAR championed the financial reporting interests of lesser developed countries (Martinez-Diaz, 2005). The IASC had long promoted its standards to lesser developed countries as a lower cost alternative to maintaining their own standard-setting infrastructures. Many lesser developed countries adopted these standards under the influence of such international bodies as the World Bank and the International Monetary Fund (IMF) (Hove, 1986; Perera, 1989; Camfferman and Zeff, 2006). Among the many long-standing concerns about the appropriateness of these standards for application in lesser developed countries, were the capacity to cope with the requirements, and the information needs

${ }^{3}$ Typically, those companies that qualified for differential reporting were those that did not have securities on issue, or were deemed not to have external users reliant on published financial reports, and/or were categorised small as determined by size criteria involving some combination of balance sheet assets, turnover, and number of staff (CAPA, 2003). 
of the main users of these financial statements (Briston, 1978; Hove, 1986; Wallace and Briston, 1993; Hassan, 1998).

The IASC's standards allowed several optional treatments and, for a time (from the late 1980s until 1995) the IASC acknowledged 'financial reporting needs' in lesser developed countries, but rejected the idea of separate standards for them (Hassan, 1998; interviews with Nobes and Walton). From the mid-1990s, as the IASC strived for IOSCO acceptance of its standards in capital markets world-wide, its accounting standards became increasingly complicated and less flexible as optional treatments were removed under the general goal of 'narrowing areas of difference' (Hassan, 1998; Gornik-Tomaszewski, 2005; Crawford et al., 2014). A potential source of embarrassment was that some listed companies claiming compliance were found not to comply fully with them, this selective compliance being described as 'IAS lite' (Cairns, 2001; interviews with Jarvis and Walton). 'The IASB and the IASC before it ... struggled ... to pull back from' this by amending IAS 1 Presentation of Financial Statements so that preparers 'either apply everything or you can't call it IAS ... it's got to be the full thing' (interview with Walton).

The IASC was 'running flat out to try to satisfy IOSCO and really nothing else would have been allowed to get in the way' (interview with Nobes). Lesser developed countries were caught between the international bodies' power to impose the IASC's standards on them and the IASC's desire for IOSCO approval (Cairns, 1997). Some countries that had adopted IAS were left 'feeling a bit disenfranchised from the products that were coming out which were increasingly focused on listed companies' (interview with Martin).

In 2000, with the IASB's emergence imminent, the IASC again rejected separate standards for entities operating in lesser developed countries (Fleming, 
2000). Recognising the IASB would have other priorities, ISAR's Lorraine Ruffing commissioned research that reformulated the problem by shifting the focus to SMEs (interview with Martin; Jarvis et al., 2008).

ISAR argued that accounting and financial reporting regulations are seldom designed specifically for SMEs, and financial reports that comply with existing accounting standards are of little use to them. Many SMEs lacked the skilled accounting personnel and infrastructure needed to implement the international standards, and they sought low-cost, understandable accounting and management guidance. Arguing that, 'reducing disclosure requirements from IAS is just not a sufficient solution in a developing economy', ISAR proposed a three-tiered financial reporting framework (UNCTAD, 2000, p. 20). This would 'provide a nested set of rules whereby, as the business grew, it would progress up a ladder of accounting evolution, starting with cash-basis accounts and then moving to simple accruals and ultimately to full IAS' (UNCTAD, 2000, p.20; interview with Fleming).

When the problem as experienced in lesser developed countries 'metamorphosed into the small and medium enterprises, ... [it] got support from ... members of more developed countries ... [and] the two expectations got moved into the SME project' (interview with Sullivan). The IASC's December 2000 handover document to the IASB acknowledged that calls for attention to small businesses were not confined to lesser developed countries, and proposed that small business preparers of financial reports were 'becoming interested' in using international standards 'to achieve comparability with larger businesses' (IASC, 2000, para 29).

\section{IASB: pressures on the standard setting agenda}

In early 2001, as the IASB commenced discussion of its technical agenda the European Commission announced that the consolidated financial reports of listed 
companies in EU countries must comply with IFRS from 2005 (Botzem, 2012). ${ }^{4}$

Australia followed with a requirement for adoption from 2005 that was not limited to consolidated financial reports. This put the IASB under pressure to achieve a 'stable platform' of standards in time for the adoption dates.

The EU regulation also allowed member states to extend the requirement to comply with the IASB's standards to entities other than listed companies (Botzem, 2012). Consequently, an added pressure on the IASB came from 'some parties within Europe ... [who sought] ... a common framework for non-listed entities' (Walton, 2001, p.12; interviews with Sullivan and Walton).

The IASB realized that applying its standards 'across the board' would cause difficulties, but was reminded that the phrasing of its constitution had been 'fought over word by word': the constitution required the IASB to 'address the needs of the international capital markets and it should concern itself exclusively with that' (Walton, 2001, p.12). ${ }^{5}$ On its technical agenda, the IASB listed 'Accounting by Small and Medium-Sized Entities and in Emerging Economies' as a research topic, delegating it to other national accounting standard-setters to determine 'whether there is a need for special guidance to clarify financial requirements in the context of financial reports' (IASB, 2001, p.8). Comments of interviewees support this:

The differential reporting side of things was parked [as] 'not now, maybe later, we're not sure whether we're the right people to do this, and certainly we don't have the time now.' (Interview with Fleming).

\footnotetext{
${ }^{4}$ During the 1990s, the EC had supported the IASC's efforts to gain IOSCO acceptance for its standards (Gornik-Tomaszewski, 2005; Botzem, 2012; Crawford et al., 2014).

${ }^{5}$ The constitution required the IASB to: 'develop ... a single set of ... accounting standards ... to help participants in the world's capital markets and other users make economic decisions; to promote the use and rigorous application of those standards; and to bring about convergence of national accounting standards and International Accounting Standards and International Financial Reporting Standards to high quality solutions' (IASCF, 2005, para. 9, emphasis added).
} 
There was ... doubt about whether the board itself was competent in setting the sort of small company standard that some people wanted because it wasn't a board comprised of people who knew about small companies ... (Interview with Whittington).

While the topic title seemed to confine the scope of attention, the explanation identified SMEs as just one of the 'certain types of enterprises' to benefit from such guidance, another example being privately held enterprises (IASB, 2001, p.8).

\section{Problem stream}

In the problem stream, there was already ISAR's reformulation of the problem for developing countries into a problem for SMEs. This reformulation was clearly of interest in Europe where opposition was building to the prospect of full international accounting standards for non-listed entities. Early findings from the World Bank's Reporting on the Observance of Standards and Codes program suggested the full standards were unduly complicated for SMEs generally and for lesser developed countries (CAPA, 2003; World Bank, 2004; Mir and Rahaman, 2005). ${ }^{6}$ Whereas previously the World Bank and IMF had tried to 'persuade countries to adopt full scale' international financial reporting standards, interviewees suggested they now began to 'push [for simplified standards] with rather more logic' (interview with Nobes). 'Certainly, the IMF was very keen ... In a lot of work with developing and

\footnotetext{
${ }^{6}$ This program commenced in the mid-1990s, especially with comparing each country's national accounting and auditing standards with the international standards, and the level of compliance with those standards. The countries assessed early in the program were Bangladesh, Bulgaria, Egypt, Jamaica, Kenya, Lithuania, Macedonia, Mauritius, Philippines, Poland, Romania, South Africa and Ukraine (see http://www.worldbank.org/ifa/rosc.html for details of each program report).
} 
emerging economies we found that there were difficulties with adopting the full blown IFRS' (interview with Sullivan).

Representatives from lesser developed regions that wanted to 'be international', but lacked the infrastructure to implement the international standards also pressed for simplified standards (IASCF, 2002; Fleming, 2002a; b; Deloitte Touche Tohmatsu, 2002a; interviews with Fleming, Jarvis, Jones, and Walton). ${ }^{7}$ However, whether simplified accounting standards alone would resolve this was debatable:

there was no point in having IAS in place if you didn't have the qualified accountants who were competent, who were familiar with standards', as well as a supportive 'regulatory environment' and a 'credible banking system.' (Interview with Fleming).

The IASB commenced 'active research work' on this project in 2002 by appointing an advisory panel to assist staff work on a detailed project proposal and changed the project title to 'Accounting and Financial Reporting by SMEs and Emerging Economies and Transitional Economies' (Deloitte Touche Tohmatsu, 2002b; IASCF, 2002, p.10; Camfferman and Zeff, 2015). ${ }^{8}$ Again, there was some ambiguity about the focus of the project. The research intention identified was whether the 'burden of compliance with international accounting standards can be reduced for small and medium-sized entities', without mention of emerging and

${ }^{7}$ These regions included Africa, Asia and Latin America. Several interviewees mentioned one Standards Advisory Council member describing the difficulties in Sri Lanka complying with standards that required actuarial estimates. One of the two actuaries in Sri Lanka had died recently.

${ }^{8}$ The panel included 'representatives of the national standard-setters of Canada, New Zealand and the United Kingdom; practitioners from Hong Kong, Sri Lanka and the Caribbean; representatives of central or regional governments' multilateral lending agencies and others' (IASCF, 2002, p. 10) 
transitional economies (IASCF, 2002, p.10). 'We didn't distinguish [between matters that] were specifically related to emerging economy issues, as opposed to issues that ... could affect SMEs around the world' (interview with Garnett). However, the IASB expected the project to 'help non-listed companies to stay within the scope of IASB standards by applying a cost-benefit test to their financial reporting, [and allow]... those seeking a public listing to make the change to IFRS without undue cost or effort' (IASCF, 2002, p.10, emphasis added). This slide in language to non-listed companies emerged because an internationally applicable, size-based approach to defining SMEs was not feasible: 'not big ... is usually done with quantitative thresholds and what is not big in [one country] is larger than gross domestic product in some [other] countries' (interview with Fleming). But the project title retained sizebased terminology and was narrowed to 'Financial Reporting by Small and Mediumsized Entities' following the advisory panel's first meeting in April 2003. ${ }^{9}$

\section{Policy stream}

The IASB's decision to omit SMEs from its standard setting agenda in 2001, 'gave impetus to' ISAR's project to develop a three-tiered financial reporting framework to facilitate progression to full IFRS (interview with Fleming). The IASB similarly sought progression, to 'draw the companies subject to the discussion ultimately into IFRS' but wanted the differences from full standards limited to reduced disclosure requirements while maintaining measurement and recognition requirements (IASCF, 2001, p.19; Deloitte Touche Tohmatsu, 2002a). ${ }^{10}$ These IASB-

\footnotetext{
${ }^{9}$ Several board members and representatives of a US organisation of private companies also attended this meeting. It was apparent that interest in the problem went beyond SMEs (Interview with Garnett).

${ }^{10}$ This was at the peak of the IASB's efforts to pursue fair value, 'defined as a selling price', in its standards (see Whittington, 2015, p.560).
} 
announced constraints influenced ISAR which observed a 'political decision' not to 'deviate from the recognition and measurement rules of full IFRS' as it developed guidelines for tier two of its framework, immediately below full compliance with IFRS (Jarvis et al., 2008, p.116). ISAR called this tier SMEGA (Accounting and Financial Reporting Guidelines for Small and Medium-sized Enterprises) (UNCTAD, 2001). It was targeted to 'significant business enterprises that do not issue public securities and in which there is no significant public interest', and contained the key policy features the IASB sought (UNCTAD, 2004, pp. iii). ${ }^{11}$

By 2003, besides the development of ISAR's tier 2 guidelines, some European countries had reportedly begun to develop their own simplified IFRS (IStaR, 2003a). By the time the IASB's advisory panel met in April 2003, an IASB policy solution was clearly being discussed: '(a) whether to add special standards for SMEs to existing IAS and IFRS or to publish a separate comprehensive IFRS for SMEs; (b) which disclosures might be simplified or eliminated for SMEs; and (c) whether differential recognition and measurement standards are appropriate' (Deloitte Touche Tohmatsu, 2003).

\section{Politics stream}

When the IASB omitted the accounting needs of SMEs from its initial standard setting agenda in 2001, it had agreed to 'review any proposals generated from outside', and to review its decision not to act if another body produced a policy solution (IASCF, 2001; Walton, 2001, p.12). In its announcement that it would develop the three tiered reporting framework ISAR urged the IASB 'and other

\footnotetext{
${ }^{11}$ This policy response contains the same slide in language, the title SMEGA suggesting a size based response and the contents covering something different.
} 
relevant international bodies' to recognize, 'that accounting by SMEs is an urgent issue for economic and social development for developed and developing countries alike' (UNCTAD, 2001, para 9).

When ISAR commenced work on its framework, it wanted 'the IASB to take over the ISAR project' (interview with Walton). While this did not occur, ISAR's actions did 'essentially force the lead' on the IASB (interview with Fleming). When it issued its tier 2 SMEGA guideline in mid-2003, ISAR urged the IASB to prioritize its project on SMEs, warning that it would 'keep the SMEGA under review in light of developments in the IASB's project' (UNCTAD, 2004, p.iv). However, as a UN guideline, SMEGA 'lacked the authority' and while some within ISAR hoped the IASB would endorse SMEGA, others advised the IASB to prevent it from becoming established by promulgating its own standard (UNCTAD, 2002; Jarvis et al., 2008, p.118; interviews with Carvallo, Martin and Walton).

The IASB remained divided over admitting the SME project onto its standardsetting agenda. Some members felt 'responsible for the fact that many countries had gone ahead and adopted full IFRS' when 'it is crystal clear that the full standards ... are far too complex for small companies' (IStaR, 2003b, p.37; interviews with Jones, Walton and Whittington). Against the background of the IASC's (and now the IASB's) struggle against selective application of the standards by listed companies, however, other board members 'saw the SME standard as a back door to demand IFRS-lite' (interview with Walton). They believed such a standard would undermine the quality of the IASB's full standards (Walton, 2001; IStaR, 2003b; interviews with Jones, Sullivan, Walton and Whittington). 'On the board, there was a lot of fear the standards would be diluted' (interview with Whittington). 
One argument against accepting the project, promoted 'particularly [by] the North Americans' was that the IASB's constitution required a single set of financial reporting standards for capital market participants (interviews with Jones and Pacter). 'I thought a single set meant one ... I didn't think a single set meant more than one' (interview with Leisenring). Those board members argued that a second set of standards was outside the IASB's mandate, seeing 'their primary responsibility as being to the large capital markets. Others said, well the capital markets reference in the IASB constitution is not only public capital markets but private capital markets and ... so you need to be a bit wider' (interview with Fleming). Evidently, the IASCF Trustees did not see the constitution as such a barrier to the SME project, the Chairman of the IASCF making public his support for the IASB to consider SMEs and lesser developed countries (see IASCF, 2002).

Pressure increased on the IASB to add the SME project to its standard setting agenda. Demand for the SME project had originated 'from the developing world' (interviews with Garnett and Jones), and the IASB's standard-setting attention was focused on achieving its 'stable platform' of standards in time for the 2005 adoption deadlines, but the Standards Advisory Council reminded the board of its 'responsibilities [to] all parts of the world and not just the Anglo-Saxon parts' (interview with Garnett). Additionally, representatives from such influential bodies as the UN, World Bank and IMF, and EU urged the IASB to include the SME project on its standard setting agenda (interviews with Fleming, Garnett, Jones, Leisenring, Nobes, Pacter, Seidenstein, and Tweedie).

[The IASB was] getting comments in from people like the World Bank, from various countries saying it's too complicated to do IFRS. ... gradually you get enough votes to say, yes, there is a problem; we just have to do it. (Interview with Tweedie). 
No doubt there would have been support from the United Nations. ... I think it is probably pressure from the EU that pushed it. (Interview with Nobes).

I wouldn't say that the [European] Commission stood out. But it was definitely supportive. (Interview with Jones).

The UN and the World Bank I think essentially approached the trustees and said that they were unhappy with the fact that the IASB was unable to make progress on a standard for SMEs. (Interview with Fleming).

\section{Agenda Entrance}

According to Kingdon, agenda entrance typically results from several factors coming together at the same time, and the critical event to understand is how the streams of activity eventually converge. In the case of the SME project, both the problem and policy proposals had come together, although both were somewhat vague, and evidently required some of Kingdon's (2011) 'bending' to bring them together.

In the problem stream, ISAR had taken the lead with its formulation of the problem as the IASB's standards being too difficult for SMEs and lesser developed countries, and the World Bank's standards and codes program provided evidence to support that. Further, as the European Commission's IFRS adoption deadline for listed companies loomed, the perceived problem for non-listed entities grew. Whereas previously, IAS-lite research findings had resulted in non-compliance with full IFRS being viewed as a problem requiring the standard-setter's action to ensure full application (Cairns, 2001), now the existence of IFRS without any allowable simplification was represented as a problem. Certainly, the perceived problem related to a broader range of entities than SMEs. 
In the policy stream, the IASB had signalled that acceptable proposals would need to start with full IFRS. By mid-2003, ISAR's tier 2 SMEGA guideline provided a model policy response but, despite the SME reference in the title that was for significant non-listed business enterprises (UNCTAD, 2004). Additionally, some European countries were reportedly developing their own simplified IFRS.

In the politics stream, there was already significant external support and a receptive mood for the SME project, and both the chairman of the IASCF Trustees and the Standards Advisory Council evidently encouraged a broader, rather than narrower interpretation of the IASB's role in the international environment. ISAR's project built at least the impression of jurisdictional competition and when ISAR issued SMEGA in 2003 this made it seem that, should the IASB not act quickly, there would emerge multiple 'adaptations of IFRS, ... everything would be a mixture over the world ...' (IStaR 2003b; interviews with Jones, Pacter and Tweedie). Despite all this support, there remained 'sharp divisions within the IASB staff leadership and also within the Board' (World Standard Setters meeting, 2003, p.5):

[Those board members] who wanted to ... [proceed with the project] ... were actually very dedicated to doing it. On the other hand, the people who opposed it on the board ... said our reason for existence is a single set of high quality standards and a single set isn't two sets, one for big and one for small. So you can understand both points of view. (Interview with Jones).

[The board] didn't want anybody else to develop standards based on IAS/IFRS. But if there was going to be a cut down version, they would do it. They wouldn't let anyone else do it. (Interview with Walton).

Suggestive of Kingdon's entrepreneur role, for agenda entrance to occur action was required from those with the ability and sufficient power to persuade or sidestep the remaining within-IASB opponents. IASB chairman Tweedie and vice 
chairman Jones had long been convinced this project should proceed, and knew the IASCF trustees supported consideration of the project (see IASCF, 2002;

Camfferman and Zeff, 2015). They approached the IASCF for further support, which resulted in a change in the constitution.

\begin{abstract}
What happened in the end, we went to the trustees and [reported a] dilemma enough board members oppose [the project] and they could block it but most board members, the majority of board members feel [the IASB] should do it ... The trustees ... amended the constitution to take away that issue that only one single set was allowed by the constitution. So they opened the way for two or three of the people who had opposed the standard to say, okay, if it is within the constitution and the trustees agree we will support it. (Interview with Jones).
\end{abstract}

Well, technically, some people could say, hey, you shouldn't be there. We thought we should be there but the way our constitution was drafted, it almost excluded them so it was really changing it to bring them in. The same way we will be under pressure to deal with not-for-profit and eventually, I suspect, public sector but that's not there yet either. So the constitution will eventually change to encompass whatever the trustees think the board should deal with. ... We [the board] felt that there was a danger we were going outside our mandate and therefore, you know, people could rightly criticise, saying you're wasting resources, why are you doing this? So we pretty well wanted to make clear that it was supported. (Interview with Tweedie).

Someone said that the IASB, they put it in legal terms, doesn't have the competence to do it because they felt that our constitution didn't allow us to do that work. So the trustees said well we'll just make it absolutely clear that this is within the scope of what the IASB could do. (Interview with Garnett).

The IASB's five yearly constitution review commenced in late 2003, and was not completed until 2005. ${ }^{12}$ However, knowledge within the IASB in mid-2003 that

\footnotetext{
12 The first question in the consultation document issued in 2003 was whether there should 'be a specific objective to address the special challenges facing small and medium-sized entities (SMEs)' (IASCF, 2003, para 4). The formal amendment in 2005 required the
} 
there would be a constitutional amendment to accommodate SMEs was sufficient to overcome most remaining arguments against agenda entrance, even if it did not persuade all of those opposed (interviews with Garnett, Pacter, and Tweedie).

What that tells you is that David was going to do [the project] anyway. ... We'll just change the constitution so that it is within our constitution. (Interview with Walton)

We never sat there and said, 'we should make this applicable' ... because we don't decide what things are applicable. Since that's not our decision, we couldn't have done that. (Interview with Leisenring).

If changing the constitution seems an extraordinary measure to overcome board resistance to the project, it was not the only such measure. Some senior members of the IASB's staff opposed the SME project, this being 'a philosophical difference' (interview with Fleming). Those staff 'felt just like Jim Leisenring that [such a project] would damage the conceptual framework because we'd have two different definitions of assets' (interview with Pacter). Sir David Tweedie was 'not pleased when discovering early in 2003, that instead of presenting a detailed project proposal, staff intended to propose to the board not to place an SME project on the Board's agenda' and, using his power as chairman, he 'had the agenda paper retracted' (Camfferman and Zeff, 2015, p.386, emphasis in original).

Usually, for the IASB's standard-setting projects the 'two most senior members of the [IASB's] technical staff' would supervise the project manager who would have more than one project to manage (IASB, 2010). However, Tweedie established special staffing arrangements for the SME project. He recruited Paul

IASB to 'take account of, as appropriate, the special needs of small and medium-sized entities and emerging economies' (IASCF, 2005, para. 2(c)). 
Pacter, long known as 'Mr Fix' for his abilities with 'politically contentious' accounting standard setting projects and appointed him Director of the SME Project (Christodoulou, 2010, p.15). In this role, Pacter reported directly to Tweedie, an arrangement that shielded him from internal opponents to the project:

Paul Pacter was appointed, not as a normal member of staff, he directly reports to David Tweedie because a normal member of staff would go through the technical director and so on and David did not want Paul Pacter to be sidetracked onto other duties or to have barriers put in his way. So Paul just reports directly to David without the normal mechanisms, to protect Paul from other board members as it were and from the technical staff. (Interview with Nobes).

I had internal opposition but I must say David Tweedie, chairman, [and] Tom Jones as vice chairman have been the two strongest supporters of this project throughout. (Interview with Pacter).

Tweedie described the benefits of this arrangement in different terms: The old IASC only had about six staff. I mean, they had very, very small staff and I think it was just a question they got bulldozed over by different priorities really. It was as simple as that. We were lucky. We got Paul Pacter, who's been doing the whole thing from start to finish and he's great and he writes very quickly, he's a clear thinker. If he hadn't done it, I think we'd be about a year or two behind, to be honest, because it's difficult to put staff onto something that's as specialised as that, especially if some of them can only stay two or three years and move on. That always causes a problem. (Interview with Tweedie).

The IASB's financial and staffing resources were known to be stretched, and it was still developing its approach to resourcing (see Camfferman and Zeff, 2015, Ch11). One interviewee suggested Pacter's recruitment had been facilitated by dedicated project-specific funding that the UN and World Bank may have helped arrange (interview with Fleming). Other interviewees denied that. Commenting on the World Bank, for example, interviewees referred to its support as 'words of 
encouragement' (interviews with Garnett, Jones, Leisenring, Seidenstein, Tweedie), and its financial support as 'in general, not for this project' (interview with Pacter). Tweedie acknowledged the IASB received 'money in general' from the World Bank but was unaware of 'anything specifically earmarked' and did not think the World Bank or any financial institution provided any financial support for the SME project, referring the question to Tom Seidenstein, the Director of Operations (interview with Tweedie). Seidenstein, who also referred to support as provided on a general basis, denied any 'specific project support or budgets' (interview with Seidenstein).

International Financial Reporting Standard for Small and Medium Enterprises was shown on the IASB's standard setting agenda from July 2003. It had clearly been transferred to its active agenda by this time, but it is not clear if a formal vote was taken. Normally entry onto the standard setting agenda requires a simple majority vote by the board:

[For] every other project that I know, there is a formal vote taken at a board meeting and the ... IASB Update newsletter says the board voted to add this project to the agenda. ... On this SME project I have never found an IASB update where they voted to add this to the agenda. They just started discussing it. ... They sort of inherited the project from the old board. It was already partly done but to my knowledge I'm not aware of an actual vote where they went around the table and raised add this to the agenda or no. (Interview with Pacter).

Review of both the IASB's Updates and the IStaR reports that would normally note the details of any vote confirms there is no record of a decision to add the project to the IASB's standard setting agenda. One board member of the time has commented in general terms on Tweedie's occasional changes to the agenda without consultation with board members, and board members' efforts to restrain that (see Camfferman and Zeff, 2015). For this project, however, that there had been significant efforts to 
achieve board agreement to the project entering the IASB's standard setting agenda is clear, and another board member suggested other reasons for the lack of a recorded vote:

There must have been [a vote] in terms of due process. I would have thought it's much more likely that it was not recorded than that it wasn't taken. If it wasn't taken it was a slip. There was certainly an informal vote taken because we had discussed it. As I say, I can't remember whether we discussed it initially in an administrative meeting or in a formal Board meeting... (Interview with Whittington).

Had there been a vote at a formal board meeting it seems unlikely that neither record of that meeting would mention it, but it does seem reasonable that by this time there was a tacit understanding and the formal vote was overlooked. Board discussion of the project commenced in July 2003, and Pacter attended this board meeting as the director of the project. At the time, he reported that the European Union requirement for IFRS had brought the issue to a head, and SME was 'not necessarily the right title' for the project (IStaR, 2003a, p.31). Pacter described the proposed policy solution to the meeting as intended 'to reduce the burden on SME and non-listed companies', and as 'a single version of IAS-lite', while chairman Tweedie described it as 'a subset of [the IASB's] standards and not a second set' (IStaR, 2003a, pp. 31-32 (emphasis added); IStaR, 2003b, p.37; IStaR, 2003a, p.33; IASB, 2003). Shortly afterwards, Pacter also presented the issue in jurisdictional terms as a question of whether the IASB should 'focus its standards towards entities that participate in public capital markets? And CEDE responsibility for developing SME GAAP to other(s); [or whether it should] set standards for SMEs as well as for entities that participate in public capital markets? [And] SEIZE the responsibility' (World Standard Setters, 2003, capitalization in original). 


\title{
Subsequent developments: IFRS for SMEs
}

It took the IASB six years (from 2003 to 2009) to promulgate its IFRS for SMEs which reduced full IFRS largely by reducing required disclosures, but also by making some changes to recognition and measurement requirements. Clearly, at the time of agenda entrance, the intentions for the standard went beyond SMEs and the IASB devised application criteria that relate to entities considered not publicly accountable, according to the IASB's interpretation of that term. ${ }^{13}$

\begin{abstract}
Most of the criteria didn't travel well between countries, or industries for that matter. ...so we had to resort to the principle, and ... it's based on the users of the accounts, ... ultimately the accounts have to satisfy users. We can't allow people to simplify them if they don't meet the needs of the user... Then we thought, of course, what about banks? You should have privately owned banks, but you will still have depositors who have an interest so the public has an interest. So we hit on the idea of publicly accountable to sort of cover that idea, it's the constituency that matters ... the people who are outside the company who don't have access to other sources of information. They're the people being served and if there are a lot of those people you don't want over-simplified accounts... (Interview with Whittington).
\end{abstract}

The size of something seems to me to be pretty irrelevant. ... the nature of the users of the financial statements is much more important. (Interview with Nobes).

Consequently, although the standard is described as 'intended for use' by SMEs, it applies to those entities that do not meet the IASB's interpretation of public accountability which does not refer to size. ISAR's tier 2 SMEGA guidelines for non-

\footnotetext{
${ }^{13}$ The application criteria of the standard define an SME as an entity that does not have 'public accountability', and interpret entities with public accountability as 'those with debt or equity instruments [that] are traded in a public capital market' or as 'hold[ing] assets in a fiduciary capacity for a broad group of outsiders as one of its primary businesses' (IASB, 2009, para 1.3).
} 
listed business enterprises seemed to provide an initial model, but whereas SMEGA excludes those entities in which there is significant public interest, the IASB's standard does not exclude such enterprises from applying the standard. ${ }^{14}$ The IASB also allows the subsidiaries of listed companies (consolidated groups) and even the parent entity to apply it in their own financial reports, provided they are not themselves publicly accountable (IASB 2009; IASB, 2015a). Countries adopting this standard may add size criteria but, in the absence of additional criteria, the standard could feasibly be applied by 'large but unlisted multinational enterprises' (Camfferman and Zeff, 2015, p.388).

As the IFRS for SMEs standard neared completion in late 2008, interviewees described it as providing 'a path towards the full standards': 'if you want to grow into IFRS, it's easier to have a set that's based on IFRS rather than something completely fresh' (interviews with Jones and Tweedie). The forthcoming standard would meet 'the demand for a simplified version of international standards' (interview with Whittington), some referring to it as small GAAP or IFRS-lite (interviews with Pacter, Seidenstein, and Sullivan). It would also be applicable to private entities (interview with Walton), and 'the subsidiaries of [EU listed] companies' (interview with Garnett). However, there remained concerns about its suitability for SMEs (interview with Whittington), and about whether this standard that would have the IASB's 'hexagon on it and ... be an authoritative pronouncement signed off by the

${ }^{14}$ The SMEGA guidelines refer to 'significant business enterprises' in which there is no 'public interest' but do not elaborate on either of these terms (UNCTAD, 2004). The IASB considered using both economic significance and public interest as criteria for application in the SME standard but subsequently dropped both, leaving only its narrow definition of public accountability. 
board... will be used inappropriately [including] ... by entities that shouldn't be using it' (interview with Fleming).

Even at the time of agenda entrance, the SME project title was known to be inappropriate, and its intended scope was wider than implied by the title (IASCF, 2002, IStaR, 2003a). During the course of the project, the IASB tried several times to change the title to one that better reflected the nature of the project, first to 'IFRS for non-publicly accountable entities' (twice, in 2004 and briefly in 2008) and then to 'IFRS for private entities' (2008) (IStaR, 2003a; IASB, 2005; IStaR, 2008; IStaR, 2009a,b,c). Each attempt was controversial, and resulted in reversion to 'IFRS for SMEs':

Almost throughout the whole project ... we defined the companies we are aiming at the same way. We have said it's an entity that's not publicly accountable and if either you're listed or you're a financial institution you are publicly accountable ... So the board ... went to non-publicly accountable for a while and then people wrote back and [objected] ... and then on top of that the trustees changed the constitution to say SME. ... So we used SME ... in the exposure [draft] and [people objected to that]. So I said we're aiming at anybody that's not public so it's private. ... [people objected]. ... We've said to the board just tell us what you want us to do. We've come up with another approach which is don't define it by the type of company but rather the type of standard. So one possibility is called Simplified IFRS. (Interview with Pacter).

We've probably got to use terms carefully. Simplified would be one way of describing it. But there's a lot of concern among some of my colleagues that we didn't produce what we referred to in shorthand as IFRS lite. ... SMEs came out first of all because that was the population that ... is not addressed by the global capital markets. ... We were deliberating the scope and wondering how to describe the entities for which the standard was intended. ... the top level all contains publicly accountable entities. Therefore the other group must be the non-publicly accountable entities. (Interview with Garnett). 
The issue of the name aroused very, very strong opinions. We always called it the SME project. I like that title. ... The reason the people who don't like it apparently oppose it is obscure. ... But they say since we refuse to define what is a small company and what is a medium company, we can't call it a Small Medium standard. ... quite a lot of the board like SME but the ones who don't really have a strong objection for that kind of semi-legalistic reason. ... I don't like any of the [other titles] we have had so far. (Interview with Jones).

I have no idea why we keep changing the title. ... most of it goes back to a fundamental misunderstanding that we are dictating who the standards apply to and we're not. ... I just said I don't care what the title is. ... I suggested Inferior IFRS as the title but that didn't win very many votes. (Interview with Leisenring).

Non-publicly accountable entities ... was such a mouthful ... Small and medium, some thought it was all for medium and not for small. Private has got different meanings in different countries, it was discovered. ... We were even thinking, now remember you shouldn't try and describe the company and just say this is Simplified IFRS ... it's very easy to say what it is, which is a cut down version of IFRS and we've got to find a snappy title that says that. That's one of the alternatives, or we just give up and say it's SMEs. ... People wouldn't like [Simplified IFRS] because it's demeaning you know, you'd have to find some other fancy title. ... it doesn't matter what we choose, it will be wrong, but they'll know what it is. (Interview with Tweedie).

The fact remained then, and remains today, that the 'IFRS for SMEs' title misrepresents the nature of the standard and, although the idea of calling it Simplified IFRS was never tested publicly, the IASB has since been describing the standard as 'good financial reporting made simple' (IASB, 2015b). In the recent postimplementation review of the standard, however, changing the title seemed not to be contemplated despite the IASB's description of it. ${ }^{15}$

\footnotetext{
${ }^{15}$ By the time the review commenced, the IASCF trustees had removed from the constitution any specific reference to SMEs, replacing it with a more flexible reference to 'a range of
} 


\section{DISCUSSION AND CONCLUSION}

The SME project that entered the IASB's standard setting agenda in 2003 seemed anomalous because the IASB's jurisdiction at the time related to the world's capital markets and a single set of accounting standards. Agenda setting is perhaps 'the single most important decision of an accounting standard setting board' (Howieson, 2009, p.579, citing Beresford). Kingdon's (2011) model of agenda setting is well suited to identifying the multiple, interacting factors underpinning agenda entrance. Drawing especially on interviews and other materials this case study of the SME project contributes several insights about the complexity of accounting standard setting at the international level, and about agenda entrance.

Importantly, the SME project reveals developments in international accounting standard setting that are of greater consequence than the innocuous IFRS for SMEs title of the standard suggests. From the time of its establishment in 2001, the IASB knew it would be unrealistic to expect 'across the board' compliance with the more stringent international standards promulgated to gain IOSCO approval in international financial markets. The tensions in the lesser developed countries that had adopted the international standards, often influenced by the World Bank, were well known, and similar tensions were likely in newly adopting countries, including the EU countries. Limiting the IASB's jurisdiction to those entities with debt or equity instruments traded in public capital markets (as preferred by board members opposed to the SME project) meant ignoring a range of other entities, which include but are not limited to SMEs. In number at least, those other entities far exceed those that do issue

size and types of entities in diverse economic settings' (IFRS Foundation 2010, (para 2(c)), and Pacter (2011), who initially chaired the review, reported that the standard applies to 'millions of companies (over 99\%)!', citing as evidence non-listed companies, rather than SMEs. 
such publicly-traded instruments. Changing the IASB's jurisdiction to facilitate agenda entrance for the SME project allows the IASB to consider the whole range of those other entities.

Kingdon emphasised the importance of language and careful treatment of controversial matters, a point also noted by other accounting standard setting researchers. Evidently, the problem as formulated for SMEs fitted the mood of the time, even though the problem went beyond SMEs and the policy solution attached to it and developed subsequently was not consistent with the problem for SMEs alone. Interviewees, both opponents and supporters of the SME project, confirmed the project was always going to produce simplified, or 'cut down IFRS.' But in the context of the IASB's efforts to require full compliance with its standards, language sensitivities meant the IASB could not agree on a 'snappy title' to capture the nature of the SME project or the eventual standard. As became apparent from the controversies surrounding attempts to change the title, the language used in private could not be used in public. The IFRS for SMEs title may have helped to blunt opposition and blur the divisions within the IASB over a project to produce a simplified version of its standards, but it also avoided attracting outside attention to the nature and wider implications of the project.

This presents potential problems for practitioners and academics, and indicates further research questions in this more complex international environment. Some may be deceived by the IFRS for SMEs title, and overlook the standard's broad application criteria. Others, aware of the broad application criteria may apply the standard to 'entities that shouldn't be using it', such as 'large but unlisted multinational enterprises' (interview with Fleming; Camfferman and Zeff (2015, p.388). There is scope for research to understand the nature of further limiting criteria, if any, imposed 
in jurisdictions adopting this standard, and to identify the size and nature of entities applying the standard in those jurisdictions. Some jurisdictions have not adopted the IFRS for SMEs standard, Australia and Canada representing just two of the nonadopters. Other research might include international comparisons of the alternative regimes. It should be noted that accounting requirements for SMEs are again becoming the focus of research attention (see for example, ICAEW, 2015).

Kingdon emphasises the importance of multiple factors, rather than a single factor for achieving agenda entrance. There was considerable external support for the SME project to proceed but in the context of IASB efforts to require full compliance with its standards, there remained significant within-IASB opposition, and opponents maintained that the wording of the IASB's constitution should prevent agenda entrance. The IASCF trustees, however, signalled support for the IASB's standards to accommodate a broader range of entities than capital market participants in countries with highly developed capital markets.

Jurisdictional competition tends to provide only a reinforcing, rather than determinative, influence on agenda entrance, but Kingdon observed how rapid agenda entrance may be when there is such competition. Agenda entrance for the SME project coincided with the issue of ISAR's SMEGA guidelines, and seemed rushed, the formal vote to record the decision possibly being overlooked. There is little to suggest ISAR represented a serious jurisdictional threat to the IASB. The IASB had observer status at ISAR's meetings and this should have been known. Walker and Robinson (1994) recommended research attention to interactions between regulatory agencies. Although such interactions were not the central focus of this study, the SME project does show how a sense of jurisdictional competition grew as ISAR pursued its project containing policy solution features the IASB itself had proposed, while also 
urging the IASB and others to act. The impression of jurisdictional competition may have involved an element of bluffing rather than actual competition. ISAR's promulgation of SMEGA in mid-2003, together with suggestions that multiple versions of simplified IFRS might emerge, helped to build a sense of urgency for the IASB to admit the project to its standard setting agenda. In the more complex international accounting standard setting environment of today, the nature and extent of interactions between regulatory agencies, including those that may seem to be competing, and alliance partners, will be a worthy topic of future research attention. Walker and Robinson (1994), and Howieson (2009) called for research attention to the roles of board and staff in accounting standard setting. Commenting in general terms on the roles of visible, as opposed to relatively invisible participants in agenda setting, Kingdon (2011) drew particular attention to the distribution of power and resources between the more visible internal participants holding high level appointments, and the less visible staff and researchers. Whereas the former have considerable power over agenda entrance decisions, staff and researchers hold relatively greater power over the form of any final policy response. Policy entrepreneurs who hold decision making power in addition to their political influence and negotiating skills are especially powerful. The within-IASB opposition to the SME project centred on the IASB's constitutional mandate that some members argued meant the project was outside the IASB's jurisdiction. Using the influence, authority and resources at their disposal, the IASB's chairman and vice chairman liaised with the IASCF trustees before the IASCF's review of the constitution commenced, and obtained agreement to an extension of the board's jurisdiction to encompass SMEs. Although the initial consultation process for the IASB's first constitutional review did not commence until late 2003, after the SME project was clearly on the IASB's 
standard setting agenda, knowledge that the constitution review would change the IASB's jurisdiction was sufficient for agenda entrance to proceed in mid-2003. As shown here, powerful board members can, and at times do, exert considerable influence behind the scenes.

The difference in power and resources is also demonstrated here with the chairman's interception of a staff recommendation to the board that the IASB not admit the SME project to its standard-setting agenda, followed by the developments that ensured it was on the agenda shortly afterwards. The chairman's 'presidential' power included the power to appoint staff, thus extending beyond merely setting the tone for the project. The recruitment of Pacter from outside the IASB even before the project had achieved agenda entrance (evidently involving additional resources), and establishment of a special reporting structure directly to the chairman, thus avoiding the usual reporting structure for standard setting projects demonstrated the chairman's ability to also influence the form of the final policy response. The IASB's chairman no longer carries the dual role of chairman and chief executive, and more recent appointments to the IASB have been less technically oriented than Tweedie (Whittington, 2015). While this implies the IASB's chairman today no longer holds such concentrated power, future research might further examine the relative roles of board and staff members, remaining alert to interactions between them.

The case of the IFRS for SMEs project reinforces the point that political activities are inherent to accounting standard setting, and that an understanding of agenda entrance is critical to understanding the accounting standard setting process. The IASB's constitution and the criteria now specified for agenda entrance project an image of accounting standard setting as largely a technical activity, with the IASB's jurisdiction and ability to place items on its agenda limited by these features of 
ostensibly rational decision making. At the time of agenda entrance, the IASB had no published criteria to guide its agenda entrance decisions, thus raising the question whether such criteria might have prevented the SME project from achieving agenda entrance. The IASB's most recent explanation of how it sets the agenda which included published criteria suggests not (http://www.ifrs.org/How-we-developstandards/Pages/Setting-the-agenda.aspx, downloaded 21 November 2016). There is no indication of how the various criteria (relevance to users; existing guidance; possibility of increased convergence; quality of standard to be developed; and resource constraints) inter-relate or may be balanced off against each other. Had such criteria existed in 2003 it seems unlikely the outcome of the IASB's agenda entrance decision would have been different. At the time, the constitutional wording of the IASB's jurisdiction presented a stronger barrier to agenda entrance than the agenda entrance criteria now published, and this study has shown how even this obstacle could be overcome by those with the power and influence to do so. The formal agenda entrance process may contain features of rational decision-making but, as shown in this case study, these barely conceal the politics and decision-making complexity of the agenda entrance decision (Kingdon, 2011).

According to Sir David Tweedie, without a formal extension of its jurisdiction, the IASB risked public criticism that the SME project was outside its jurisdiction. He expected the IASB's jurisdiction to 'change to encompass whatever the trustees think the board should deal with', thus implying the statement of the IASB's jurisdiction (and, by extension, any agenda entrance criteria) should be flexible. Since this agenda entrance decision, the wording of the IASB's constitution has changed from a level of specificity about its jurisdiction that threatened to bar agenda entrance for the SME project to such vagueness today that it seems unlikely to 
limit the IASB's continued adaptation to the changing international accounting standard setting environment. The current reference in the constitution to 'a range of sizes and types of entities in diverse economic settings' may now support 'more wideranging' IASB ambitions, potentially including international jurisdiction over both public sector and not-for-profit financial reporting (IFRS Foundation, 2010, para 2(c); 2012, p.13; Botzem, 2012; interview with Tweedie). Such possibilities promise a rich seam of future research into the IASB's standard setting activities. 


\section{REFERENCES}

Abdel-Khalik, R. (1983), Financial Reporting by Private Companies: Analysis and Diagnosis. Financial Accounting Standards Board, Stamford, Connecticut.

Ackrill, A. and A. Kay (2011), 'Multiple Streams in EU Policy-Making: The Case of the 2005 Sugar Reform', Journal of European Public Policy, Vol. 18, No. 1, pp. $72-89$.

Ackrill, A., A. Kay and N. Zahariadis (2013), 'Ambiguity, Multiple Streams and EU Policy', Journal of European Public Policy, Vol. 20, No. 6, pp. 871-887.

Alexandrova, P., M. Carammia and A. Timmermans (2012), 'Policy Punctuations and Issue Diversity on the European Council Agenda', Policy Studies Journal, Vol. 40, No. 1, pp. 69-88.

Bache, I. (2013), 'Measuring Quality of Life for Public Policy: An Idea Whose Time Has Come? Agenda-setting Dynamics in the European Union', Journal of European Public Policy, Vol. 20, No. 1, pp. 21-38.

Botzem, S. (2012), The Politics of Accounting Regulation: Organizing Transnational Standard Setting in Financial Reporting, Edward Elgar Publishing Inc., Cheltenham, UK.

Briston, R.J. (1978), 'The Evolution of Accounting in Developing Countries', International Journal of Accounting Education and Research, Vol. 14, pp. 105120.

Cairns, D. (1997), 'The Future Shape of Harmonization: A Reply', The European Accounting Review, Vol. 6, No. 2, pp. 305-348.

Cairns, D. (2001), 'Financial Reporting - IAS Compliance Survey 2000 - IAS Lite is Alive and Well', Accountancy, May, p. 98.

Camfferman, K., and S.A. Zeff (2006), Financial Reporting and Global Capital Markets: A History of the International Accounting Standards Committee 1973-2000, Oxford University Press, New York.

Camfferman, K. and S.A. Zeff (2015), Aiming for Global Accounting Standards: The International Accounting Standards Board 2001-2011, Oxford University Press, Oxford.

CAPA (Confederation of Asian and Pacific Accountants) (2003), A Framework of Differential Reporting — A Response to ISAR's Accounting and Financial 
Reporting Guidelines for Small and Medium-sized Enterprises, Confederation of Asian and Pacific Accountants, Kuala Lumpur.

Carsberg, B.V., M. Page, A. Sinhall and I. Waring (1985), Small Company Financial Reporting. Prentice Hall and Institute of Chartered Accountants in England and Wales, London.

Christodolou, M. (2010), 'Raising Standards: Profile Paul Pacter: International Standard Setter', Accountancy Age, April, pp. 12-15.

Cobb, R.W. and C.D. Elder (1972), Participation in American politics:the Dynamics of Agenda-Building. Allyn and Bacon, Boston

Crawford, L., J. Ferguson, C. Helliar and M. Power (2014), 'Control Over Accounting Standards Within the European Union: The Political Controversy Surrounding the Adoption of IFRS 8', Critical Perspectives on Accounting, Vol. 25, No. 45, pp. 304-318.

Deloitte Touche Tohmatsu (2002a), 'Accounting by Small and Medium-sized Entities and in Emerging Economies', Notes from the IASB Meeting with National Standard Setters 21-22 January 2002', retrieved 23 March 2011, from, www.iasplus.com/en/meeting-notes/iasb/2002/agenda_0201nss.

Deloitte Touche Tohmatsu (2002b), 'Additional agenda projects' Notes from the IASB Meeting 16-19 April 2002', retrieved 11 February 2016 from, http://www.iasplus.com/en/meeting-notes/iasb/2002/agenda_0204/agenda134

Deloitte Touche Tohmatsu (2003), 'Notes from the IASB Meeting with National Standard Setters 24-25 April 2003', retrieved 10 June 2011 from, www.iasplus.com/en/meeting-notes/iasb/2003/agenda_0304nss,

Eissler, R., A. Russell and B. Jones (2014), 'New Avenues for the Study of Agenda Setting', Policy Studies Journal, Vol. 42, S1, pp. S71-S86.

Fleming, C. (2000), 'IASC's Legacy Document', IASC Insight, December, p. 15.

---. (2002a), 'IFRSs and Smaller Entities', IASB Insight, January, pp. 15-16.

---. (2002b), 'Accounting and Reporting by Small and Medium-sized Entities', IASB Insight, October, pp. 15-16.

Gornik-Tomaszewski, S. (2005), 'Antecedents and Expected Outcomes of the New Accounting Regulation in the European Union', Research in Accounting Regulation, Vol. 18, pp. 69-103.

Harvey, D. and P. Walton (1996), Differential Reporting - An Analysis, The Foundation for Manufacturing Industry, London. 
Hassan, N. A. (1998), 'The Impact of Socioeconomic and Political Environment on Accounting System Preferences in Developing Economies', Advances in International Accounting, Suppl. 1, pp. 43-88.

Hepp, G.W. and T.W McRae (1982), 'Accounting Standards Overload: Relief is Needed', Journal of Accountancy, May, pp. 52-62.

Hove, M.R. (1986), 'Accounting Practices in Developing Countries: Colonialism's Legacy of Inappropriate Technologies', International Journal of Accounting Education and Research, Vol. 22, pp. 81-100.

Howieson, B.A. (2009), 'Agenda Formulation and Accounting Standards Setting: Lessons from the Standard Setters', Accounting and Finance, Vol. 49, No. 3, pp. 577-598.

IASB (2001), Press Release: IASB Announces Agenda of Technical Projects. 31 July 2001, retrieved 20 May 2007 from, www.iasplus.com/en/binary/resource/iasb0107.pdf

---. (2003), 'IASB Meets the SAC', IASB Insight, July, pp. 1-21.

---. (2005), 'Accounting Standards for Non-Publicly Accountable Entities', IASB

Update, February, pp. 1-6.

---. (2009), IFRS for SMEs, IASB, London.

---. (2010), Project Planning, retrieved 5 August 2010 from,

http://www.ifrs.org/How+we+develop+standards/Project+planning.htm

---. (2015a), IFRS for SMEs. IFRS, London.

---. (2015b), Comprehensive Review of the IFRS for SMEs, retrieved 16 January 2016

from, http://www.ifrs.org/IFRS-for-SMEs/Comprehensive-review-IFRS-for-

SMEs/Pages/default.aspx

IASC (2000), Transition Report, IASC, London.

IASCF (2001), Annual Report, IASCF, London.

---. (2002), Annual Report, IASCF, London.

---. (2003), Identifying Issues for International Accounting Standards Committee

Foundation: An Invitation to Comment, IASCF, London.

---. (2005), Changes in the IASCF Constitution:A report of the IASC Foundation

Trustees, IASCF, London.

ICAEW (2015), SME Accounting Requirements: basing policy on evidence, ICAEW,

London

IFRS Foundation (2010), Constitution. IFRS Foundation, London. 
---. (2012), Report of the Trustees' Strategy Review 2011. IFRS as the Global

Standards: Setting a Strategy for the Foundation's Second Decade. Retrieved

March 2015 from, http://www.ifrs.org/About-us/IFRS-

Foundation/Oversight/Strategy-

Review/Documents/TrusteesStrategyReviewFeb2012.pdf.

IStaR (2003a), 'Standards for Small and Medium-sized Entities', IStaR International

Standard Setting Report No 2003-07 July 2003.

---. (2003b), 'Standards for Small and Medium sized Entities', IStaR International

Standard Setting Report No 2003-09 September 2003.

---. (2008), 'IFRS for SMEs', IStaR International Standard Setting Report No 2008-

05 May 2008.

---. (2009a), 'IFRS for SMEs', IStaR International Standard Setting Report No 2009-

01 January 2009.

---. (2009b), 'IFRS for Non-Publicly Accountable Entities', IStaR International

Standard Setting Report No 2009- 03 March 2009.

---. (2009c), 'IFRS for Non-Publicly Accountable Entities', IStaR International

Standard Setting Report No 2009-04 April 2009.

Jarvis, R. (1996), Users and Uses of Financial Statements: A Literature Review, ICAEW, London.

Jarvis, R., R. Martin and P. Walton (2008), 'Chapter IX: ISAR and Accounting by SMEs', In, UNISAR. Promoting Transparency in Corporate Reporting: A Quarter Century of UNiSAR, United Nations, Geneva, pp. 113-120.

Johnson, L. T., and R.J. Swieringa (1996), 'Anatomy of an Agenda decision: Statement No. 115', Accounting Horizons, Vol. 10, No. 2, pp. 149-179.

Jones, S., S.F. Rahman and P. Wolnizer (2004), 'Accounting Reform in Australia: Contrasting Cases of Agenda Building', Abacus, Vol. 40, No. 3, pp. 379-404.

Kingdon, J.W. (2011), Agendas, Alternatives and Public Policies, updated second edition, Longman, Boston.

Klumpes, P.J.M. (1994), 'The Politics of Rule Development: A Case Study of Australian Pension Fund Accounting Rule-making', Abacus, Vol. 30, No. 2, pp. $140-159$.

Martinez-Diaz, L. (2005), 'Strategic Experts and Improving Regulators: Explaining the IASC's Rise to Global Influence', 1973-2001. Business and Politics, Vol. 7, No. 3, pp. 1-26. 
Mir M.Z. and S. Rahaman (2005), 'The Adoption of International Accounting Standards in Bangladesh: An Exploration of Rationale and Process', Accounting Auditing \& Accountability Journal, Vol. 18, No. 6, pp. 816-841.

Mitnick, B.M. (1980), The political economy of regulation, Columbia University Press, New York.

Morris, J. (1999), 'State Implementation of National Water Quality Policy: Policy Theory, Policy Streams and (un)intended Consequences', Public Works Management Policy, Vol. 3, pp. 317-330.

Pacter, P. (2011), Use of International Financial Reporting Standards Around the World, IFRS Foundation, London.

Palmer, J., (2015), 'How do Policy Entrepreneurs Influence Policy Change? Framing and Boundary Work in EU Transport Biofuels Policy', Environmental Policy, Vol. 24, No. 2, pp. 270-287,

Perera, M.H.B. (1989), 'Accounting in Developing Countries: A Case for Localised Uniformity', British Accounting Review, Vol. 21, pp. 141-158.

Richards, D. (1996), 'Elite Interviewing: Approaches and Pitfalls', Politics, Vol. 16, No. 3, pp. 199-204.

Robinson, N. (2000), The Politics of Agenda Setting: A Car and the Shaping of Public Policy, Ashgate Publishing Ltd, England.

Ryan, C. (1998), 'The Introduction of Accrual Reporting Policy in the Australian Public Sector: An Agenda Setting Explanation', Accounting, Auditing and Accountability Journal, Vol. 11, No. 5, pp. 518-539.

Solomons, D. (1983), 'The Political Implications of Accounting and Accounting Standard setting', Accounting and Business Research, Vol. 13, No. 50, pp. $107-118$.

UNCTAD (2000), Accounting by Small and Medium-Sized Enterprises: Report by the UNCTAD Secretariat, April, Geneva.

---. (2001), Agreed Conclusions on Accounting by Small and Medium-Sized Enterprises. TD/B/COM.2/ISAR/1.4, September.

---. (2002), Report of the Intergovernmental Working Group of Experts on International Standards of Accounting and Reporting on its Nineteenth Session - 25 to 27 September 2002. UNCTAD, Geneva. 
---. (2004), Accounting and Financial Reporting Guidelines for Small and Mediumsized Enterprises (SMEGA) - Level 2 guidance, UNCTAD, Geneva.

Walker, R.G. and P. Robinson (1993), 'A Critical Assessment of the Literature on Political Activity and Accounting Regulation', Research in Accounting Regulation, Vol. 7, pp. 3-40.

---. (1994), 'Competing Regulatory Agencies with Conflicting Agendas: Setting Standards for Cash Flow Reporting in Australia', Abacus, Vol. 30, No. 1, pp. $18-43$.

Wallace, R.S.O. and R. Briston (1993), 'Improving the Accounting Infrastructure in Developing Countries', Research in Third World Accounting, Vol. 2, pp. 201224.

Walton, P. (2001), 'IASB Work Programme', World Accounting Report, Vol. 4, No. 4, pp. 10-12.

Whittington, G. (2015), 'Measurement in Financial Reporting: Half a Century of Research and Practice', Abacus, Vol. 51, No. 4, pp. 549-571.

World Bank (2004), Report on the Observance of Standards and Codes (ROSC) Overview of the ROSC Accounting and Auditing Program January 2004, World Bank.

World Standard Setters Meeting (2003), Accounting by Small and Medium Sized Entities, power point presentation. Obtained from P.Pacter.

Young, J.J. (1994), 'Outlining Regulatory Space: Agenda Issues and the FASB', Accounting Organizations and Society, Vol. 19, No. 1, pp. 83-109.

Zahariadis, N. (2008), 'Ambiguity and Choice in European Public Policy', Journal of European Public Policy, Vol. 15, No. 4, pp. 514-530.

Zeff, S.A. (2002), 'Political Lobbying on Proposed Standards: a Challenge to the IASB', Accounting Horizons, Vol. 16, No. 1, pp. 43-54. 